PUBLIPRENEUR POLIMEDIA: JURNAL ILMIAH

JURUSAN PENERBITAN POLITEKNIK NEGERI MEDIA KREATIF

Vol. 7, No. 1, July 2019

Submitted: 5 July 2019

Revised: 15 July 2019

Accepted: 30 July 2019

\title{
NOISE LEVEL INVESTIGATION (L-MIN AND L-MAX) IN PRINTING LABORATORY AT POLITEKNIK NEGERI MEDIA KREATIF, JAKARTA
}

\author{
Antinah Latif \\ Politeknik Negeri Media Kreatif, Jakarta \\ E-mail: ms.antinahlatif@gmail.com
}

\begin{abstract}
Printing is one of the activities that have job risks for its workers. One of the risk of works in printing is the presence of physical environment factor. This study aims to determine the noise level with different types of machines in the printing lab at Politeknik Negeri Media Kreatif, Jakarta. The study design used in this research is descriptive obtained through direct measurements using Sound Level Meters in digital printing work areas, Computer to Print machines (pre-press), 4 color sakura brand printing machines (press), and production machines in the postpress machine that is a folding, cutting machine, wire sewing machine, binding machine and press machine. Obtained an average of different noise levels each section under $85 d B A$ tolerated by law.
\end{abstract}

Keyword: Noise level; printing technology; occupationah health safety

\section{INVESTIGAS LEVEL KEBISINGAN (L-MIN dan L-MAX) DI LAB PERCETAKAN POLITEKNIK NEGERI MEDIA KREATIF, JAKARTA}

\begin{abstract}
ABSTRAK Percetakan merupakan salah satu kegiatan yang memiliki risiko pekerjaan bagi para pekerjanya. Salah satu risiko pekerjaan di percetakan adalah adanya factor lingkungan fisik kebisingan. Penelitian ini bertujuan untuk menentukan level kebisingan dengan jenis mesin yang berbeda-beda di lab percetakan di Politeknik Negeri Media Kreatif, Jakarta. Desain studi yang digunakan dalam penelitian ini adalah deskriptif yang diperoleh melalui pengukuran secara langsung menggunakan Sound Level Meter di area kerja digital printing, mesin Computer to Print (pra cetak), mesin cetak 4 warna merk sakurai (cetak), dan mesin produksi di bagian pasca cetak yaitu mesin pengompit,/ pelipat, masin potong, mesin jahit kawat, mesin pengeleman dan mesin press. Didapatkan ratarata tingkat kebisingan yang berbeda setiap bagian dan masih di bawah 85 desibel yang telah ditetapkan oleh aturan pemerintah.
\end{abstract}

Kata kunci: kebisingan; percetakan; K3 (Kesehatan dan Keselamatan Kerja)

\section{PENDAHULUAN}

Indonesia merupakan salah satu negara berkembang yang mengalami pertumbuhan dan kemajuan di bidang Industri. Salah satu industri yang terus mengalami perkembangan dan pembaharuan di bidang teknologi adalah industri percetakan (Ekawandani, 2016). (Setyaningrum \&
Widjasena, 2014)) menyatakan bahwa perkembangan industri yang semakin pesat, dapat berakibat meningkatkan potensi bahaya dan penyakit akibat kerja. Potensi bahaya yang sering dialami oleh para pekerja di industri meliputi enam potensi bahaya meliputi fisik, kimia, biologi, ergonomik dan psiko-sosial (Starovoytova, 2018). 
Adapun potensi bahaya di industri percetakan adalah solvent, tinta, akrilate, adhesive, pigment organik dan non organik, aromatik, hidrokarbon, timbal, paper dust, dan kebisingan. (Tsai et al., 2016).

Industri percetakan disebut sebagai polutan terbesar dan menghasilkan risiko kesehatan kepada para pekerjanya (Prica et al., 2016); (Livesley EJ, Rushton L, English JS, 2002). Industri percetakan termasuk salah satu industri yang menggunakan teknologi berupa mesin-mesin yang memiliki sumber kebisingan saat melakukan produksi ((Shama, 2009)).

Kebisingan merupakan faktor lingkungan fisik yang berpengaruh pada kesehatan kerja dan merupakan salah satu faktor yang dapat menyebabkan beban tambahan bagi tenaga kerja (Sasmita \& Elystia, 2016). Kebisingan merupakan stressor yang mengenai pendengaran (auditory stressor) dan dapat menyebabkan gangguan terhadap kesehatan baik secara langsung maupun tidak langsung (Rusiyanti, dkk., 2012).

Tingkat kebisingan di percetakan dapat melebihi $100 \mathrm{dBa}$ menurut Organisasi Buruh Internasional Tahun 2008. Mihailovic (2010) menyatakan bahwa temuan dari berbagai negara seperti di Amerika Serikat menunjukkan bahwa rata-rata paparan kebisingan mencapai $85 \mathrm{dBA}$ atau lebih besar dengan waktu paparan mencapai 8 jam per hari sebanyak $43 \%$ di 34 perusahaan bidang percetakan. Adapun di Singapura menunjukkan rerata 89 $\mathrm{dBA}$, begitu juga di bagian cetak rotogravure tingkat kebisingan mencapai 71-93 dBA. Di Indonesia, industri kemasan semen berkisar antara
89, sampai 94,4 dBA. Tingkat kebisingan tersebut melebihi NAB yang ditetapkan dalam Peraturan Menteri Tenaga Kerja dan Transmigrasi No. PER/13/MEN/X/2011 tentang Nilai Ambang Batas Faktor Fisika dan Faktor Kimia di Tempat Kerja yaitu sebesar 85 dBA (Adriyani, 2017).

Gangguan pendengaran dan keseimbangan akibat kerja belum mendapat perhatian penuh, padahal gangguan ini menempati urutan pertama dalam daftar penyakit akibat kerja di Amerika dan Eropa dengan proporsi 35\%, di Indonesia berkisar antara $30-50 \%$. Beberapa efek samping kebisingan non auditori yang dirangkum oleh (Mihailovic et al., 2011)) mencakup kurang konsentrasi, sakit kepala, gangguan tidur, depresi, peningkatan laju pernapasan, isolasi sosial, dan risiko kecelakaan yang lebih besar. Selain itu, kebisingan dapat menyebabkan kelainan kardiovaskular seperti denyut nadi lebih cepat, Penyakit jantung koroner, dan hipertensi. Adapun gangguan auditori akibat kebisingan diatas NAB memberikan efek yang merugikan pada tenaga kerja, terutama resiko mengalami penurunan daya pendengaran yang terjadi secara perlahan - lahan dan waktu cukup lama dan tanpa disadari oleh tenaga kerja tersebut (Sasmita,dkk 2016). Gangguan pendengaran juga berhubungan dengan organic solvent yang digunakan pada percetakan. Beberapa penelitian epidemilogi menghubungkan antara kebisingan dengan organic solvent bahwa keberadaan organic solvent dapat menambah gangguan system pendengaran ((Mihailovic et al., 2011)). 
Berdasarkan gambaran dari pendahuluan di atas, perlunya melakukan Penilaian dan Evaluasi Lingkungan Kerja. Penilaian dan evaluasi lingkungan kerja merupakan tahap penilaian karakteristik dan besarnya potensi-potensi bahaya yang mungkin timbul, sehingga bisa untuk menentukan prioritas dalam mengatasi permasalahan. Evaluasi bahaya yang tampak nyata dilakukan dengan inspeksi. Hasilnya harus dibandingkan dengan rujukan standar yang pernah dipublikasikan. Dengan demikian, pentingnya dilakukan penilaian.

Kebisingan di industri percetakan dapat terjadi saat proses cetak, dan pasca cetak. Mesin cetak dinilai memiliki tingkat kebisingan yang tinggi. Laboratorium percetakan di Polimedia terdiri dari digital printing dan cetak offset. Cetak offset ini terdiri dari tiga proses yaitu pra cetak, saat cetak, dan pasca cetak. Di Laboratorium percetakan, belum ada investigasi terperinci tentang besarnya paparan kebisingan di laboratorium percetakan baik di digital printing maupun cetak offset.

\section{METODE PENELITIAN}

Jenis penelitian yang diambil adalah penelitian deskriptif. Lokasi penelitian ini dilakukan di laboratorium percetakan Politeknik Negeri Media Kreatif Jakarta pada Tahun 2019. Jumlah titik sampling pengukuran kebisingan 8 titik. Untuk dapat membandingkan tingkat kebisingan pada 4 lokasi berbeda tersebut maka pengukuran harus dilakukan dengan jarak dan ketinggian yang sama. Ukuran ketinggian ditetapkan masing- masing \pm 1,5 meter. Pada setiap titik lokasi, pengukuran kebisingan dilakukan dengan menggunakan alat Sound Level Meter (SLM) dengan satuan dBA. Alat SLM (Sound Level Meter) adalah alat pengukur suara dengan metode kerjanya menangkap perubahan tekanan udara yang terjadi akibat adanya benda bergetar yang selanjutnya akan menggerakkan meter penunjuk pada SLM. Sedangkan alat yang digunakan untuk mengukur nilai ambang pendengaran adalah Audiometer.

Adapun cara pengukurannya adalah (1) memasang Sound Level Meter dengan setting "fast"; (2) menempatkan pada posisi yang telah ditentukan. Ketinggian lebih kurang 1,5 meter, tepat di atas kepala operator. Adapun jarak dari sumber bising lebih kurang 3 meter; (3) menghidupkan Sound Level Meter, set frekuensi A kemudian setting pada posisi fast model Leq selama 30 detik dan Setelah itu (4) membaca tingkat kebisingan, mencatat, dan mematikan Sound Level Meter.

Pada penelitian ini tidak
menggunakan analisis perhitungan Tingkat Kebisingan Sinambung Setara atau leq (Equivalent Continous Noise Level). Leq adalah nilai tingkat kebisingan dari kebisingan yang berubah-ubah (fluktuatif) yang setara dengan tingkat kebisingan dari kebisingan tetap selama 10 menit. Penelitian ini hanya mengukur Lmin dan Lmax setiap pengukuran.

Adapun analisis yang digunakan dalam penelitian ini adalah analisis deskriptif. Penelitian ini dibagi menjadi 3 tahap, yaitu tahap persiapan, tahap pelaksanaan penelitian, dan tahap analisa data. 
Tabel 2. Titik Pengukuran Kebisingan

\begin{tabular}{|c|l|l|}
\hline no & \multicolumn{1}{|c|}{ Lokasi } & Keterangan \\
\hline 1 & $\begin{array}{l}\text { Mesin Computer to } \\
\text { Plate (CTP) }\end{array}$ & Pra cetak \\
\hline 2 & $\begin{array}{l}\text { Mesin Prosesor } \\
\text { Plate }\end{array}$ & Pra cetak \\
\hline 3 & $\begin{array}{l}\text { Digital printing } \\
\text { (Xerox) }\end{array}$ & cetak \\
\hline 4 & $\begin{array}{l}\text { Offset printing } \\
\text { presses }\end{array}$ & cetak \\
\hline 5 & $\begin{array}{l}\text { Cutters/mesin } \\
\text { pemotong }\end{array}$ & Pasca cetak \\
\hline 6 & $\begin{array}{l}\text { Folders } / \text { mesin } \\
\text { pelipat }\end{array}$ & Pasca cetak \\
\hline 7 & Mesin laminating & Pasca cetak \\
\hline 8 & Mesin press & Pasca cetak \\
\hline
\end{tabular}

Pada penelitian ini tidak semua bagian dilakukan pengukuran karena jadwal cetak yang tidak sesuai saat pengukuran. Contoh mesin yang tidak dilakukan pengukuran adalah mesin pengeleman dibagian pasca cetak.

\section{HASIL DAN PEMBAHASAN}

Pengukuran kebisingan ini menggunakan pedoman Serbian 114 Environment Monit Assess (2011): 181: 111-122. Salah satu isi Panduan tersebut adalah pengukuran pada mesin pemotong diukur dengan kecepatan 10 detik dan untuk mesin lainnya seperti pelipat dan mesin cetak offset dapat mengukur dengan kecepatan 30 detik. Panduan tersebut digunakan dalam beberapa riset kebisingan yang dilakukan di Serbia.

Berikut ini merupakan gambaran tingkat kebisingan dari berbagai mesin di lab percetakan kampus Polimedia Jakarta yang diambil pada Tahun 2019.

\section{Tingkat Kebisingan}

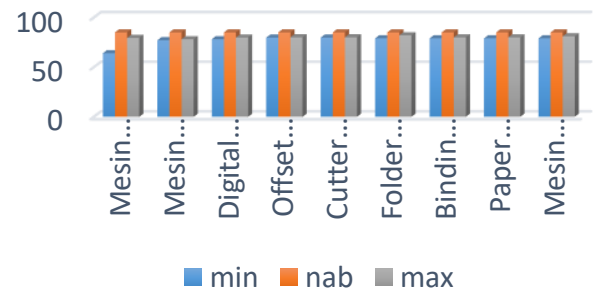

Gambar 1. Level Kebisingan Lmin, Lmax, dan NAB dari Berbagai Jenis Mesin

Berdasarkan gambaran tingkat kebisingan di atas, Level kebisingan didapatkan dari berbagai jenis mesin yang ada pada lab percetakan. Pengukuran kebisingan dilakukan pada mesin digital printing, mesin Computer to plate (CTP), Mesin Prosesor Plat, mesin cetak offset, mesin folder, mesin potong, mesin pengeleman, dan mesin kawat. Pengukuran tersebut dilakukan pada proses pra cetak, cetak dan pasca cetak. Hasil pengukuran level kebisingan semua mesin secara umum bervariasi yaitu antara 64-82 Dba (Tabel 3). Level kebisingan tertinggi terdapat pada mesin pelipat dengan 82 dBA. Dengan demikian, level kebisingan pada lab percetakan di Politeknik Negeri Media Kreatif masih tergolong aman menurut Peraturan Menteri Tenaga Kerja dan Transmigrasi No. PER/13/MEN/X/2011 tentang Nilai Ambang Batas Faktor Fisika dan Faktor Kimia di Tempat Kerja yaitu sebesar 85 dBA (Adriyani, 2017). Adapun level kebisingan terendah terdapat pada mesin laminating pada bagian pasca cetak dan pada bagian pra cetak khususnya mesin CTP dengan masingmasing 23,1 desibel dan 64 desibel 
(Tabel 3).

Tabel 3. Hasil Pengukuran Kebisingan di Laboratorium Percetakan.

\begin{tabular}{|l|l|c|c|c|}
\hline no & Jenis mesin & Lmin & NAB & Lmax \\
\hline 1 & Mesin CTP & 64 & 85 & 79,4 \\
\hline 2 & $\begin{array}{l}\text { Mesin } \\
\text { Prosesor Plat }\end{array}$ & 77,1 & 85 & 78,1 \\
\hline 3 & $\begin{array}{l}\text { Digital } \\
\text { printing }\end{array}$ & 78,1 & 85 & 79,8 \\
\hline 4 & $\begin{array}{l}\text { Offset printing } \\
\text { presses }\end{array}$ & 79,8 & 85 & 80,04 \\
\hline 5 & $\begin{array}{l}\text { Cutters/mesi } \\
\text { n pemotong }\end{array}$ & 78,2 & 85 & 79,5 \\
\hline 6 & $\begin{array}{l}\text { Folders/mesi } \\
\text { n pelipat }\end{array}$ & 79 & 85 & 82 \\
\hline 7 & $\begin{array}{l}\text { Mesin } \\
\text { laminating }\end{array}$ & 23,1 & 85 & 26 \\
\hline 8 & Mesin press & 79 & 85 & 81 \\
\hline & Total & 69,7 & 85 & 73,23 \\
\hline
\end{tabular}

Berdasarkan Tabel di atas, tingkat kebisingan maksimal tertinggi adalah pada mesin pelipat/ folder; mesin press dan mesin offset 4 warna namun masih di bawah NAB yang telah ditetapkan oleh pemerintah yaitu 85 desibel. Adapun rerata LMin pada berbagai mesin didapatkan 69,7 desibel dan rerata LMax adalah 73,23 desibel. Hal tersebut berbeda dengan penelitianpenelitian sebelumnya yang telah dilakukan di berbagai negara seperti Amerika, Singapura, Malaysia, Arab Saudi dan Serbia yang menunjukkan bahwa level kebisingan di industry percetakan melebihi NAB yang telah ditetapkan pemerintah. Hal tersebut dikarenakan pengukuran dilakukan pada skala industry dengan produksi dapat melebihi 8 jam perhari. Sedangkan pada penelitian ini hanya dilakukan pada lab percetakan skala kecil dan waktu kerja dibatasi hanya 8 jam perhari.

Penelitian yang dilakukan di Novi Sad, Serbia menunjukkan bahwa digital press color menghasilkan level kebisingan mencapai 70,7 desibel, sedangkan pada penelitian ini menghasilkan level kebisingan L-Min 78,1 . Adapun level kebisingan mesin cetak offset pada penelitian ini adalah (79,8-80,04), termasuk level kebisingan tertinggi pada lab percetakan. Hal tersebut sesuai dengan penelitian di Serbia yang menunjukkan bahwa mesin offset menghasilkan level kebisingan yang tinggi (75.2-94.8) dBA. ((Mihailovic et al., 2011)). Pada mesin pelipat/ folder di bagian pasca cetak menunjukkan level kebisingan yang tinggi, sesuai dengan penelitian yang dilakukan oleh Mihailovic dkk (2011) yang menyebutkan bahwa mesin pelipat menghasilkan level tertinggi pada penelitian tersebut (81.2 (2.9) - 92.4 (7.2)) dengan nilai Leq 87,7 Dba.

Berdasarkan hasil pengamatan selama pengambilan data, para tenaga atau operator di lab percetakan masih banyak yang belum menggunakan APD secara lengkap untuk perlindungan diri dari berbagai macam bahaya lingkungan kerja. Meskipun data menunjukkan kebisingan di bawah standard, namun penggunaan APD seharusnya tetap dilaksanakan sebagai wujud proteksi diri dan upaya minimalisasi penyakit akibat kerja. Adapun jenis APD yang dapat 
digunakan untuk mencegah kebisingan adalah earmuff, ear plug dan ear canal caps. Hal tersebut menguatkan pernyataan dari Mihailovic dkk (2011) bahwa penggunaan APD dilakukan ketika kebisingan mencapai 75 desibel meskipun masih di bawah 85 karena gangguan kehilangan pendengaran baik temporer maupun permanen selama 8 jam per hari dapat menimbulkan gangguan setelah beberapa tahun kemudian

Reinhold dan Tint (2009) menjelaskan bahwa hubungan antara level risiko kebisingan dengan masalah kesehatan dibagi dalam 5 level risiko. Dalam penelitian ini, level risiko masuk dalam kategori tolerable dan justified yaitu di bawah 80 dan di antara 80-85 desibel. Sehingga, gangguan kesehatan yang dapat terjadi adalah perasaan tidak bahagia, kesulitan dalam berkomunikasi, stress dan kelelahan pada level risiko tolerable. Adapun masalah kesehatan yang mungkin muncul ketika kebisingan di antara 8085 adalah seperti gangguan di atas ditambah dengan penurunan kapasitas kognitif, reflex otot stress pada komunikasi. Dengan demikian, gangguan kesehatan tidak hanya terjadi pada auditori saja tapi juga pada aspek psikologi. Hal tersebut semakin menimbulkan bahaya jika terpapar dengan solvent organic yang sering ada pada industry percetakan. Beberapa epidemiolog menyebutkan bahwa terdapat hubungan antara paparan organic solvent dengan kebisingan.

Penelitian ini masih harus dilanjutkan untuk mengetahui Leq dan hubungan antara paparan organic solvents dengan kebisingan.

\section{SIMPULAN}

Berdasarkan hasil penelitian yang telah dilakukan di bagian pra cetak, cetak, dan pasca cetak serta digital printing dapat disimpulkan bahwa beberapa mesin di lab percetakan rata-rata tingkat kebisingan yaitu rentang 69,7-73,23 desibel yang masih sesuai dengan standard NAB yaitu 85 desibel.

\section{DAFTAR PUSTAKA}

Adriyani, R. (2017). Hubungan Pajanan Kebisingan dengan Tekanan Darah dan Denyut Nadi pada Pekerja Industri Kemasan Semen. Jurnal Kesehatan Lingkungan Indonesia, 16(1), https://doi.org/10.14710/jkli.16.1.2 9-36

Ekawandani, N. (2016). Analisis Risiko Paparan Isopropanol Pada Pekerja Offset Printing. Tedc, 10(3), 191-196.

Livesley EJ, Rushton L, English JS, W. H. (2002). The prevalence of occupational dermatitis in the UK printing industry. Occup Environ Med, 59, 487-493.

Mihailovic, A., Grujic, S. D., Kiurski, J., Krstic, J., Oros, I., \& Kovacevic, I. (2011). Occupational noise in printing companies. Environmental Monitoring and Assessment, 181(1-4), 111-122.

https://doi.org/10.1007/s10661010-1817-5

Prica, M., Kecić, V., Adamović, S., Radonić, J., \& Sekulić, M. T. (2016). Occupational Exposure to Hazardous Substances in Printing Industry. Proceedings of 8 th International Engineirng Symposium 
at Banki, 1-8.

Sasmita, A., \& Elystia, S. (2016). EVALUASI

TINGKAT KEBISINGAN SEBAGAI

UPAYA

PENGELOLAAN

KESEHATAN

$D A N$

KESELAMATAN KERJA ( K3 ) DI

UNIT PLTD / G TELUK LEMBU PT

PLN PEKANBARU. 15(September), 34-42.

Setyaningrum, I., \& Widjasena, B. (2014). Analisa Pengendalian Kebisingan Pada Penggerindaan Di Area Fabrikasi Perusahaan Pertambangan. 2(April), 267-275.

Shama, M. E. (2009). PERCEPTIONS AND PRACTICES REGARDING MEASURES AMONG PRINTING WORKERS Abstract: 33(2), 155-174.

Starovoytova, D. (2018). Hazards and Risks at Rotary Screen Printing ( Part 6/6): Control of Chemical Hazards via Cleaner Production Approaches Hazards and Risks at Rotary Screen Printing ( Part 6/6 ): Control of Chemical Hazards via Cleaner Production Approaches. April.

Tsai, C. J., Mao, I. F., Ting, J. Y., Young, C. H., Lin, J. S., \& Li, W. L. (2016). Quality of Chemical Safety Information in Printing Industry. Annals of Occupational Hygiene, 60(3), 361-370.

https:// doi.org/10.1093/annhyg/ mev079 